\title{
Nursing Care of Women Who Suffered Sexual Violence ${ }^{1}$
}

\author{
Maria José dos Reis² \\ Maria Helena Baena de Moraes Lopes ${ }^{3}$ \\ Rosângela Higa ${ }^{4}$ \\ Aloísio José Bedone ${ }^{5}$
}

The aim of this study was to characterize the nursing care, provided to women who suffered sexual violence, treated at The Women's Hospital-CAISM/UNICAMP. A retrospective, descriptive study performed using 146 nursing care records of women attended from June 2006 to May 2007. The results showed that the majority of attendances occurred during the day period, that there was consistency between the interventions and the nursing diagnoses identified, and that women reported having received guidance in accordance with the protocol of the program. The nursing consultation time was greater at night $(p=0.0227)$ and the women frequently understood the health risks resulting from sexual violence $(p=0.0072)$, the use of antiretrovirals according to their daily activities $(p=0.0397)$ and they were more focused on the purpose of the serology $(p=0.0351)$. We concluded that the care provided was shown to be appropriate and of a better quality in the nightshift period.

Descriptors: Sexual Violence; Nursing Evaluation Research; Nursing Care; Women's Health.

\footnotetext{
${ }_{1}$ Paper extrated from Master's Thesis "Vivência de enfermeiros na assistência à mulher que sofreu violência sexual" presented to Programa de Pós-graduação do Departamento de Tocoginecologia, Faculdade de Ciências Médicas, Universidade Estadual de Campinas, SP, Brazil.

${ }^{2}$ RN, M.Sc., Hospital da Mulher, Universidade Estadual de Campinas, SP, Brazil. E-mail: mjreis03@hotmail.com.

${ }^{3}$ RN, Free Lecture, Associate Professor, Faculdade de Ciências Médicas, Universidade Estadual de Campinas, SP, Brazil. E-mail: mhbaena@fcm.unicamp.br.

${ }^{4}$ RN, Hospital da Mulher, Universidade Estadual de Campinas, SP, Brazil. Doctoral Student, Faculdade de Ciências Médicas, Universidade Estadual de Campinas, SP, Brazil. E-mail: rosangelahiga@bol.com.br.

${ }^{5}$ Physician, Associate Professor, Faculdade de Ciências Médicas, Universidade Estadual de Campinas, SP, Brazil. E-mail: bedone@unicamp.br.
}

Corresponding Author:

Maria José dos Reis

Rua Tenente João Batista de Godoy, 17

Jardim das Oliveiras

CEP 13043-640 Campinas, SP, Brasil

E-mail: mjreis03@hotmail.com 


\title{
Atendimento de enfermagem às mulheres que sofrem violência sexual
}

O objetivo deste estudo foi caracterizar a assistência de enfermagem prestada pelo enfermeiro às mulheres que sofreram violência sexual, atendidas no Hospital da Mulher -CAISM/Unicamp. Foi realizado estudo retrospectivo e descritivo com 146 fichas de atendimento de enfermagem a mulheres, entre junho de 2006 a maio de 2007. Os resultados mostraram que a maioria dos atendimentos ocorreu durante o período diurno, houve coerência entre as intervenções e os diagnósticos de enfermagem identificados, e as mulheres relataram que receberam orientações de acordo com o protocolo do programa. O tempo da consulta de enfermagem foi maior no período noturno $(p=0,0227)$ e essas mulheres mais frequentemente conheciam os riscos de saúde, decorrentes da violência sexual ( $p=0,0072)$, adequaram os horários do antirretrovirais, de acordo com suas atividades diárias ( $p=0,0397)$, e estavam mais orientadas quanto à finalidade das sorologias $(p=0,0351)$. Conclui-se que o atendimento prestado mostrou-se adequado e com melhor qualidade no plantão noturno.

Descritores: Violência Sexual; Pesquisa em Avaliação de Enfermagem; Cuidados de Enfermagem; Saúde da Mulher.

\section{Atención de enfermería a mujeres que sufren violencia sexual}

\begin{abstract}
Nuestro objetivo fue caracterizar la asistencia prestada por los enfermeros a las mujeres que sufrieron violencia sexual atendidas en el Hospital de la Mujer-CAISM (UNICAMP). Fue realizado un estudio retrospectivo y descriptivo con 146 fichas de atención de enfermería de mujeres atendidas entre junio de 2006 a mayo de 2007. Los resultados mostraron que la mayoría de las atenciones ocurrieron durante el período diurno, hubo coherencia entre las intervenciones y los diagnósticos de enfermería identificados y las mujeres relataron que recibieron orientaciones de acuerdo con el protocolo del programa. El tiempo de consulta de enfermería fue mayor en el período nocturno $(p=0,0227)$ y se constató que esas mujeres frecuentemente conocían los riesgos de salud provenientes de la violencia sexual $(p=0,0072)$, adecuaban los horarios de los antirretrovirales de acuerdo con sus actividades diarias $(p=0,0397)$ y estaban más orientadas en cuanto a la finalidad de las serologías $(p=0,0351)$. Concluimos que la atención prestada se mostró adecuada y con mejor calidad en el plantón nocturno.
\end{abstract}

Descriptores: Violencia Sexual; Investigación en Evaluación de Enfermería; Atención de Enfermería, Salud de la Mujer.

\section{Introduction}

In the last two decades, the entities linked to human rights and international institutions such as the World Health Organization (WHO) and the Pan-American Health Organization (PAHO) have recognized violence against women as a public health problem due to the diverse injuries to the women's health, such as gynecological, gastrointestinal and psychiatric disorders, drug and alcohol abuse $^{(1)}$.
Considering the types of violence suffered by women, sexual violence is one of the most frequent with serious implications for physical and mental health. However, it has been ignored and is rarely included in programs of sexual and reproductive health, however, in recent years it has received attention from various social sectors in Brazil, since it is a historical and cultural issue that affects women of all ages and social classes(2). 
As the physical trauma of genitalia or other body parts may or may not be present, the physical and psychological consequences can be immediate or long term. Given this fact, it is necessary that health professionals are informed about this subject and know how to evaluate the signs and symptoms, in order to prevent and treat the consequences ${ }^{(3)}$. Since the theme of sexual violence was very recently incorporated into some undergraduate courses in the medical field(4) it became necessary to discuss this phenomenon in their curriculum in order to prepare and train the professional to assist this population(3). The quality of care, as attested by the large adherence of the clientele attended, and the possibility to serve as a center of sensitization and training within the health area, indicates that the participation of the University is necessary and useful in addressing sexual violence(5).

With this perspective, in the University of Campinas (UNICAMP), the Center for Integral Attention to Women's Health (The Women's Hospital - CAISM), a teaching hospital specializing in the care of women's health and newborns, has become one of the pioneering services in the country to assist women who suffer sexual violence, creating a program called Special Care, which has individual multidisciplinary protocols and a trained team aimed at preventing unwanted pregnancy, sexually transmitted diseases (STDs), including the human immunodeficiency virus (HIV) and promoting the physical, psychological and social recuperation of sexually assaulted women.

According to the nursing protocol, urgent/immediate (up to 5 days after the assault) and later (after 5 days) care is offered 24 hours a day, prioritized at the moment at which a client arrives at the service in a private and calm place. The client is received by the nurse who obtains data on anamnesis; executes the medical prescription, such as emergency contraception (EC) and chemoprophylaxis for viral and non-viral STDs, performs nursing interventions according to nursing diagnoses identified, and gives guidance related to medical treatment. In the outpatient follow-up, which begins after seven days of immediate/ emergency or later care, nursing care is provided for six months ${ }^{(6)}$.

All nurses who work in the program received training in the attendance; however, the nursing care had not yet been the object of analysis. It is known that an inadequate posture of the health professional, due to personal values and beliefs can interfere with the quality of care provided and with treatment adherence. Indeed, high rates of discontinuity in the adherence to antiretroviral therapy (HAART) have been observed due to lack of understanding of the proposed treatment ${ }^{(7)}$.
Moreover, in the literature, reports of some difficulties in sensitizing the team are found, both in the user embracement and in the need to break down prejudice in the acceptance of the statements of women, this difficulty could be related to cultural and moral values that most health professionals have in relation to the theme ${ }^{(4)}$. It can be perceived then, that the training of the teams should include both, technical knowledge as a reflection on their attitudes, about their concepts of violence, and direct contact with victims of aggression. Because, often, the concern of health professionals in treating the victim using only the care protocol and not being attentive to the issues that involve the subjectivity of the other person, along with haste in the care can produce the opposite result to that expected, i.e. further violence ${ }^{(8)}$. This aspect cannot be neglected, thus, constant technical and psychological support for the teams is important, in order not to deviate from the goal of non-patronizing humanized $\operatorname{care}^{(9)}$.

Faced with this, it was necessary to understand the nursing care in the user embracement, with a view to improving the nurse-client relationship, favoring a more effective and collaborative user embracement for the adhesion to the proposed treatment. Therefore, the aim of this study was to characterize the nursing care provided, at The Women's Hospital - CAISM / UNICAMP, to women who had suffered sexual violence.

\section{Methods}

A retrospective, descriptive study was conducted. Due to the particular characteristic of the study, to characterize the care provided in a specific service, it was chosen to analyze the data corresponding to one year of attendance. Taking as base the mean annual attendance from the years 2003 to 2005, the examination of approximately 175 records was expected.

An instrument constructed specifically for this study was used, which allowed the characterization of nursing care by collecting data from nursing consultation records in the client register completed during the nursing attendance. The instrument was evaluated by two researchers with experience in the area of women's health before being used. All the records of women treated between June 2006 and May 2007 were included and those that were not located or did not contain an immediate/emergency nursing care record excluded. During this period 172 women that had suffered sexual violence were assisted. 26 records were excluded, being that 15 were not found due to incorrect registration of medical record number in the attendance control book of 
the service, and 11 that did not contain an immediate/ emergency nursing care record. Therefore, 146 records were analyzed.

For the characterization of nursing care, data were collected in the form of immediate/emergency care (Single record of Special Immediate Care - Multidisciplinary). The following variables were considered: duration of attendance (less than 30 minutes, 30 to 60 minutes, or 60 minutes or more) period of service (day or night), completion of the instrument (complete or partial); nursing diagnoses reported in a checklist (yes or no) or added, and nursing interventions consistent with the nursing diagnoses and collaborative problems identified (yes, no or partially).

From the first nursing consultation record in outpatient services (Special Care Outpatient - Nursing Consultation - New Case) data were obtained about the attendance. Recorded in this document are, in the form of a check-list, according to the report of the women, whether they received guidance from the nurse during the user embracement in immediate/emergency care (yes, no or do not remember) in relation to: risk of acquiring STDs or unwanted pregnancy; vaccination card and first dose of vaccine for hepatitis $B$; adequacy of HAART schedule; adequacy of schedule of taking their medicines according to the user's daily activities, side effects of HAART, purpose of serology collected, nutrition, oral hydration and condom use.

Data were entered into an Excel ${ }^{\circledR}$ spreadsheet (version 2003, Microsoft Corporation), and the absolute and relative frequencies of the variables were calculated. To compare care between the day and night periods, the Chi-square or Fisher Exact test were used as indicated, and the logistic regression test. The level of significance was $5 \%(p<0.05)$.

The study was approved by the Research Commission of the Obstetrics and Gynecology Department/CAISM of UNICAMP and the Research Ethics Committee of the Faculty of Medical Sciences of UNICAMP (Protocol No. 546/2006) in accordance with the standards recommended by Resolution 196/96 of the National Health Council. The Research Ethics Committee waived the application of the Free Prior Informed Consent form.

\section{Results}

The 146 records analyzed represented $84.9 \%$ of the attendances carried out during the study period. A percentage of $74.7 \%$ of nursing records were fully completed, $91 \%$ had identified nursing diagnoses, and $73.6 \%$ had nursing interventions. Between $70.8 \%$ and $83.9 \%$ of women reported having received counseling/ interventions according to the protocol of the program.

Table 1 presents the characteristics of nursing care in the Special Care Program - Immediate, it was observed that half of the visits lasted 60 minutes or more, most of which occurred during the day period and the instruments were filled out completely. There was consistency of interventions with nursing diagnoses and collaborative problems identified.

Table 1 - Characterization of nursing care in the Special Care Program - Immediate. CAISM/UNICAMP, 2006-2007

\begin{tabular}{|c|c|c|c|}
\hline Characteristics & Categories & $\mathbf{n}$ & $\%$ \\
\hline \multirow[t]{3}{*}{ Duration of attendance in minutes $n=79$} & $<30$ & 13 & 16.5 \\
\hline & 30 to 60 & 27 & 34.2 \\
\hline & 60 or more & 39 & 49.4 \\
\hline \multirow[t]{2}{*}{ Period of attendance $(n=135)^{*}$} & Day & 83 & 61.5 \\
\hline & Night & 52 & 38.5 \\
\hline \multirow[t]{2}{*}{ Completion of instrument $(n=146)$} & Complete & 109 & 74.7 \\
\hline & Partial & 37 & 25.3 \\
\hline \multirow[t]{2}{*}{ Identification of ND*in the check-list $(n=144)$} & Yes & 131 & 91.0 \\
\hline & No & 13 & 9.0 \\
\hline \multirow[t]{3}{*}{ Nursing interventions consistent with $\mathrm{ND}^{*}$ and or $\mathrm{CP}^{*}$ identified $(\mathrm{n}=144)$} & Yes & 106 & 73.6 \\
\hline & No & 25 & 17.4 \\
\hline & Partially & 13 & 9.0 \\
\hline \multirow[t]{4}{*}{$N D^{*}$ added $(n=25)$} & Anxiety & 8 & 32.0 \\
\hline & Fear & 8 & 32.0 \\
\hline & Risk of infection & 3 & 12.0 \\
\hline & Others & 6 & 24.0 \\
\hline
\end{tabular}

* day 07:00 to 19:00 and night 19:00 to 07:00 / ND= Nursing Diagnosis / $\mathrm{CP}=$ Collaborative Problems

It was observed that $70.8 \%$ to $83.9 \%$ of women who attended the outpatient nursing consultation reported having received recommendations according to the nursing protocol (Table 2). 
Table 2 - Guidelines received from the nurses in the Special Care Program - Immediate, according to the women attended. CAISM/UNICAMP, 2006-2007

\begin{tabular}{|c|c|c|c|}
\hline Characteristics & Categories & $\mathbf{n}$ & $\%$ \\
\hline \multirow[t]{3}{*}{ Understanding of risks for the woman $n=106$ ) } & Yes & 79 & 74.5 \\
\hline & Do not remember & 25 & 23.6 \\
\hline & No & 2 & 1.9 \\
\hline \multirow[t]{2}{*}{ Delivery of Vaccination Card $(n=106)$} & Yes & 75 & 70.8 \\
\hline & No & 31 & 29.2 \\
\hline \multirow[t]{2}{*}{ Adequate scheduling of $\mathrm{ARV}^{*}(\mathrm{n}=93)$} & Yes & 78 & 83.9 \\
\hline & No & 15 & 16.1 \\
\hline \multirow[t]{3}{*}{ Information about adequate scheduling $(n=93)$} & Yes & 79 & 84.9 \\
\hline & Do not remember & 7 & 7.5 \\
\hline & No & 7 & 7.5 \\
\hline \multirow[t]{3}{*}{ Information about the collateral effects of the $\mathrm{ARV}^{*}(n=93)$} & Yes & 76 & 81.7 \\
\hline & Do not remember & 12 & 12.9 \\
\hline & No & 5 & 5.4 \\
\hline \multirow[t]{3}{*}{ Information about the serology $(n=93)$} & Yes & 74 & 79.6 \\
\hline & Do not remember & 14 & 15.1 \\
\hline & No & 5 & 5.4 \\
\hline \multirow[t]{3}{*}{ Information about nutrition and oral hydration $(n=93)$} & Yes & 75 & 80.6 \\
\hline & Do not remember & 13 & 14.0 \\
\hline & No & 5 & 5.4 \\
\hline \multirow[t]{3}{*}{ Information about the use of condoms $(n=92)$} & Yes & 71 & 77.2 \\
\hline & Do not remember & 15 & 16.3 \\
\hline & No & 6 & 6.5 \\
\hline
\end{tabular}

*ARV $=$ antiretrovirals

Comparing care between day and night periods, it can be observed in Table 3 that the length of nursing consultation was greater at night, and that women attended in this period more often: knew the health risks resulting from sexual violence; made use of ARV drugs at times appropriate to their daily activities; and were more informed about the purpose of serological tests for STD and HIV collected in the immediate care.

Table 3 - Nursing care characteristics in the Program of Assistance of Victims of Sexual Violence which were significantly different between the day and night periods $(n=146)$. CAISM/UNICAMP, 2006-2007

\begin{tabular}{|c|c|c|c|c|c|c|}
\hline \multirow{2}{*}{ Characteristics } & \multirow{2}{*}{ Categories } & \multicolumn{2}{|c|}{ Day* } & \multicolumn{2}{|c|}{ Night $^{*}$} & \multirow{2}{*}{ p-value ${ }^{* *}$} \\
\hline & & $\mathbf{n}$ & $\%$ & $\mathbf{n}$ & $\%$ & \\
\hline \multirow[t]{5}{*}{ Duration of attendance in minutes $(n=79)$} & & & & & & 0.0227 \\
\hline & $<30$ & 11 & 24.4 & 02 & 5.9 & \\
\hline & 30 to 60 & 17 & 37.8 & 10 & 29.4 & \\
\hline & 60 or more & 17 & 37.8 & 22 & 64.7 & \\
\hline & Total & 45 & 100.0 & 34 & 100.0 & \\
\hline \multirow[t]{4}{*}{ Understanding of health risks $(n=101)^{\star \star *}$} & & & & & & 0.0072 \\
\hline & Yes & 42 & 65.6 & 33 & 89.2 & \\
\hline & No & 22 & 34.4 & 04 & 10.8 & \\
\hline & Total & 64 & 100.0 & 37 & 100.0 & \\
\hline \multirow[t]{4}{*}{ Adequate scheduling of ARV $(n=88)^{\star \star *}$} & & & & & & 0.0397 \\
\hline & Yes & 41 & 77.4 & 33 & 94.3 & \\
\hline & No & 12 & 22.6 & 02 & 5.7 & \\
\hline & Total & 53 & 100.0 & 35 & 100.0 & \\
\hline \multirow[t]{4}{*}{ Information about the serology $(n=88)^{\star * *}$} & & & & & & 0.0351 \\
\hline & Yes & 37 & 69.8 & 32 & 91.4 & \\
\hline & No & 16 & 30.2 & 3 & 8.6 & \\
\hline & Total & 53 & 100.0 & 35 & 100.0 & \\
\hline
\end{tabular}

Day 07:00 to $19: 00$ and Night 19:00 to $07: 00 / * *$ Fisher Exact Test / ***Considering only the records that contained information of the period and the characteristic in question. 
The logistic regression test was carried out to verify if the characteristics of nursing care, as shown in Table 3, were influenced by the time of consultation, independent of that being day or night. There were no significant differences observed.

\section{Discussion}

Research conducted at The Woman's Hospital - CAISM/ UNICAMP between October 1999 and February 2002(9) showed that at that time, just over $80 \%$ of women who suffered sexual violence attended the first control with the gynecologist, while less than $50 \%$ returned for the second visit and only $29 \%$ completed the six-month follow-up.

In this study, as some records were excluded from analysis, one can consider that at least $84.9 \%$ of women who attended the service returned to the service for the first consultation of outpatient follow-up with the multidisciplinary team, which suggests that there was a slight increase in service adhesion or at least the maintenance of their index. One possible explanation for this may be the fact that, currently, the outpatient follow-up is performed at The Woman's Hospital - CAISM/UNICAMP, concentrating the attendance of the multidisciplinary team in the same physical space, and the women who miss the first appointment are invited by members of that team.

Women who suffer sexual violence require more than the simple application of protocols, they expect to receive a dignified attendance, respectful and welcoming, which protects them from re-victimization, because they need emotional support, since their self-esteem and their ego may have been injured more severely than any physical injury that may be presented(3).

When the women maintain ties with the personnel of the team after the termination of treatment this reveals that there was quality in the user embracement, indicates that they liked the service, and manifests as a willingness to return ${ }^{(4)}$, thus, it is necessary that the professional show sympathy and understanding, willingness to listen with respect and interest, and be prepared to give emotional support in the first attendance.

Although, in a previous study conducted at The Women's Hospital - CAISM/UNICAMP ${ }^{(10)}$ the majority of cases of sexual violence (79.5\%) occurred between 18:00 and 06:00, actually the majority of nursing attendances $(61.5 \%)$ were realized during the day period. It is likely that the violence continues to occur more frequently at night, but a woman looks for help in the morning.
The time spent in care, 60 minutes or more, demonstrates the welcoming attitude in the nurseclient relationship, since the nurse must be able to have a comprehensive and neutral stance, i.e. not demonstrate personal manifestations(11) that might interfere with the user embracement and, consequently, in the adherence to treatment. In fact, researchers believe that individualized attention is the great ally of improved adhesion and the nurse-client relationship, the most important tool in for its effectiveness ${ }^{(12)}$. Trust is the key element of this relationship and for it to occur it is necessary to establish empathy, credibility in the professional, respect for privacy and, above all, the understanding of the information and the client's behavior.

To systematize, individualize, manage and assume the role of provider of nursing care together with the team, basing this scientifically, is the goal and desire that nurses have demonstrated ${ }^{(13)}$. In addition, to characterize the quality of care offered it is important to consider the steps of the nursing process, which includes the anamnesis, diagnoses, results and nursing interventions. Faced with this, it can be consider that nursing care performed at The Women's Hospital CAISM/UNICAMP has been adequate and, in the way it is proposed, permits assistance for the needs of the nurses, once the service is systematized, individualized, and allows the nurses to provide direct care, based on scientific evidence.

The results show that the vast majority of women confirmed having been guided by the nurses regarding emergency contraception (EC), the risks and prevention of STD/HIV, the importance of condom use, the use of ARVs and their side effects during the user embracement, which suggests the information has been given in an adequate way. These orientations are the basis of attendance in order that, among other problems, virgin women suffer a higher risk of HIV infection, with the perforation of the hymen, and considering that $60 \%$ of women do not use any contraceptive method, the vulnerability to pregnancy is evident, therefore, understanding and correct use of EC and of HAART in the first hours after the rape can prevent pregnancy and the risk of acquiring $\mathrm{HIV}^{(14)}$.

However, there is a need to closely monitor professionals to understand conditions that might be implicated in the increased risk of not understanding the information offered, which can lead to noncompliance with treatment. A survey which evaluated the adherence to HIV chemoprophylaxis treatment of women who experienced 
sexual violence showed that noncompliance was attributed to psychological and/or emotional disorders and not understanding of the treatment ${ }^{(6)}$. Another study, carried out in our department, showed that among women who completed six months of follow-up with the infectologist, the incidence of abandonment of chemoprophylaxis treatment of HIV was 1.5 times greater among those with incomplete elementary education when compared to those who had a university education ${ }^{(15)}$.

Most of the nurses on the night shift took 60 minutes or longer to perform an attendance. It is likely that time spent was directly related to the fact of the multidisciplinary team not being complete during the night and that the nurses need to provide immediate interventions when the identification of the nursing diagnoses related to psychological or social changes in an attempt to minimize the feelings and/or psychosocial difficulties before they receive specialized assistance. The night shift comprises 12 hours of work and could be a facilitating factor, allowing nurses to devote more time to nursing user embracement/consultation, which would justify a higher quality of care in this period. However, the question is whether the longer consultation time can lead to a higher quality of care, since the characteristics of care were not influenced by the consultation time and were by the period in which women were received. Considering this fact, a plausible explanation would be the different preparation of the nurses on the two shifts. This study did not characterize the nurses responsible for care, but it is possible that nurses working night shifts are more experienced, with more training to act in the area and, because they are better prepared to develop this type of care, can carry it out with higher quality.
Other possible explanations must be sought, such as the possibility that the nurses of the day-shift more frequently isolate themselves or "anesthetize" their emotions, so that they do not interfere in the interaction with others, causing distancing, forgetting that to provide an effective interaction with women who suffer sexual violence and their families, is of fundamental importance not only in the user embracement, but also in the recovery at a situation that is full of anguish, revulsion and insecurity.

\section{Conclusions}

The time spent, of 60 minutes or more, demonstrated that the nurses had a welcoming attitude during the immediate /emergency care of women who suffered sexual violence. The return to nursing consultations in the outpatient sample was $84.9 \%$. The account of these women that they had received orientation on health risks resulting from sexual violence and the purpose of serology collected, as well as the use of ARV drugs in schedules appropriate to their daily activities, indicated that the immediate/emergency nursing care was adequate, in accordance with the protocol established by the institution and followed the steps of the nursing process. Women received more information in the night period, in which the consultation was longer, but this fact alone does not justify the higher quality of care of the night shift team.

This study did not investigate the length of experience and training of nurses involved, nor the quality of the nurse-client relationship. Therefore, these aspects can be the subjects of other studies aimed at evaluating the quality of nursing care.

\section{References}

1. Rede Saúde (BR). Rede Nacional Feminista de Saúde e Direitos Reprodutivos. Jornal da Rede Saúde - São Paulo [Internet]; 1999. [acesso em: 12 setembro 2007]. Disponível em: http:// www.redesaude.org.br/jornal.htm

2. Bedone $A J$, Faúndes $A$. Atendimento Integral às Mulheres Vítimas de Violência Sexual: Centro de Assistência Integral à Saúde da Mulher da Universidade Estadual de Campinas Fórum. Cad Saúde Pública. 2007;23(2):465-9.

3. Faúndes A, Rosas CF, Bedone A, Orozco LT. Violência Sexual: Procedimentos indicados e seus resultados nos atendimentos de urgência de mulheres vitimas de estupro. Rev Bras Gineco. Obstet. 2006;28(2):26-35.

4. Oliveira EM Barbosa RM, Moura AAVM, Kossel KV, Mourelli K, Botelho LFF, Stoianov M. Atendimento às Mulheres Vítimas de Violência Sexual: Um estudo qualitativo. Rev Saúde Pública. 2005;39(3): 376-82.
5. Mattar R, Abrahão AR, Andalaft J Neto, Colas OR, Schroeder I, Machado SJR, et al. Assistência multiprofissional à vítima de violência sexual: a experiência da Universidade Federal de São Paulo. Cad Saúde Pública. 2007;23(2):459-64.

6. Higa R, Mondaca AA, Reis MJ, Lopes MHBM. Atendimento à mulher vítima de violência sexual: protocolo de assistência de enfermagem. Rev Esc Enferm USP. 2008; 42(2):377-82.

7. Diniz NMF, Almeida LCG, Ribeiro BCS, Macêdo VG. Women victims of sexual violence: adherence to chemoprevention of HIV. Rev. Latino-Am. Enfermagem. [internet]. 2007; 15(1): 7-12. [acesso em: 12 setembro 2007]. Disponível em: http:// www.scielo.br/pdf/rlae/v15n1/v15n1a02.pdf

8. Bedone $A J$, Faúndes A. Atendimento integral às mulheres vítimas de violência sexual: Centro de Assistência Integral à Saúde da Mulher, Universidade Estadual de Campinas. Cad Saúde Pública. 2007; 23(2):465-9. 
9. Correa MEC, Labronici LM, Trigueiro TH. Sentir-se impotente:Um sentimento Expresso por Cuidadores de Vítimas de Violência Sexual. Rev. Latino-Am. Enfermagem. 2009 maiojunho;17(3):289-94.

10. Oshikata CT, Bedone A J, Faúndes A. Atendimento de emergência a mulheres que sofrem violência sexual: características das mulheres e resultados até seis meses pósagressão. Cad Saúde Pública 2005; 21(1):192-9.

11. Ministério da Saúde (BR). Secretaria de Políticas de Saúde. Departamento de Gestão de Política Estratégico. Área Técnica Saúde da Mulher. Normas sobre a prevenção sobre prevenção e tratamento dos agravos resultante da violência sexual contra a mulher e o adolescente. Brasília: Ministério da Saúde; 2002. [acesso em: 10 abril 2006]. Disponível em: http://bvsms.saude. gov.br/bvs/publicacoes/caderno6_saude_mulher.pdf
12. Figueiredo RM, Sinkoc VM, Tomazim CC, Gallani MCBJ, Colombri MRC. Adherence of AIDS patients to treatment with antiretroviral drugs in a university hospital: difficulties observed and suggestions of interventions. Rev. Latino-Am. Enfermagem. [internet]. 2001; 9(4):50-5. [acesso em: 12 setembro 2007]. Disponível em: http://www.scielo.br/pdf/rlae/v9n4/11483.pdf 13. Carraro TE, Kletemberg DF, Gonçalves LM. O ensino da metodologia da assistência de enfermagem no Paraná. Rev Bras Enferm. 2003;56(5):499-501.

14. Drezett J, Baldacini I, Nisida IVV, Nassif VC, Nápoli PC. Estudo da adesão à quimioprofilaxia anti-retroviral para a infecção por HIV em mulheres sexualmente vitimadas. Rev Bras Ginecol Obstet. 1999; 21(9):539-44.

15. Garcia MT, Figueiredo RM, Moretti ML, Resende MR, Bedone AJ, Papaiordanou PMO. Postexposure prophylaxis after sexual assaults: a prospective cohort study. Sexual Transm Dis.2005; 32(4):214-9. 